\title{
Editorial
}

\section{Making Rural Transformation Happen: Turning Stumbling Blocks Into Road to Success}

“How did you go bankrupt?” Bill asked.

"Two ways," Mike said. "Gradually and then suddenly."

The dialogue above is from Ernest Hemingway's 1926 novel, The Sun Also Rises.

Perhaps, we are going bankrupt in the same way, beyond our control, of course. To speak ruthlessly, for several years now, we have been falling so deeply into a sort of "economic dependency trap" (Helin, 2006, 2010) that we are going bankrupt gradually with some alarming signs in a host of areas including education, healthcare, and agro-based economy, leading to awful costs, which have already started buzzing up in our ears, and imaginably, we are waiting for that unintended Bang! moment (Mauldin, 2014) which seems to happen sometime suddenly. However, we do not want to see that unfortunate outcome of giving up more and more of our self-reliance since we are in some way convinced that things will improve and thus also hold a solemn belief that things can be turned around.

As indicated in the above paragraph, over dependence on the external agencies is becoming a major hurdle that we have not been able to overcome rather we are swept away in the flood of dependence. Much of our actions reflect that we are more often than not "watering the leaves and starving the roots" (Arutyunova \& Clark, 2013, p. i) - we are bringing in focus the superficial, and concealing the real agenda. Moreover, we are habituated to seek 'quick fix' solutions to our enduring development problems; unfortunately falling into the dependency trap laid by the development partners. In fact, the backing of 


\section{R. K. Dhakal}

development agencies is imagined to offer great fortune to rural people through easier and better access to services and control over assets (Atchoarena \& Gasperini, 2003) since their targets are customarily the rural communities and more particularly the poor people. The reality, by contrast, has been depressing (Arutyunova \& Clark, 2013; Munck \& O'Hearn, 1999). This suggests that we are gradually falling (in fact, we have already fallen) into a choreographed dependence - we know that it is being staged - in such a way that recently it has become next to impossible to get out of this trap. Now the subtle question is how to use this trap for our maximum benefit.

It is now worthwhile to reflect on what we have not relied upon for, rather than what we relied upon for. With most of the development initiatives, we are dealing with "context-free agent-centered dependencies" (Bozsahin, 2016, p. 102). Rather than accepting our failure and taking corrective measures, and proving how development partners are pulling the wool over our eyes, we change our development criteria, definitions, and conditions to suit them even more greatly so that they can dance to the tune of their interest. Let's take an example of literacy (to cover functional literacy) and net enrolment rate in education. By showing the superficial numbers, we have, for sure, increased our reliance on the others, especially development partners, but have we really made significant progress in those areas? Right from the top level policy prioritization to distribution of resources at the local level, we have seen the presence of some 'experts'. Essentially, the experts are people from somewhere else, which means they are oftentimes 'outsiders', and 'others'. To reflect back on my experience as a teacher, I had seen the expert (trainer) as someone from outside of my institution, let him or her be my classmate during college or even my student on the issue that he or she was going to talk about. This and similar experiences compel many to misconstrue that we do not have experts within and/or around us. Is it not odd where our own presence makes the experts' presence trivial, and yet we accept them as 'experts'? Can we not become experts from within? Can we not determine our future ourselves? And above all, can we not become masters of ourselves? These and similar key questions make us feel more vulnerable; yet these very questions, when we become reflective, encourage us to think squarely about channeling the relationships of dependence into interdependence. Therefore, such questions on whether we need development partners will not lead to binary answers in yes or no, rather require us to analyse, or evaluate them before we welcome them, giving way for mutual partnership for rural transformation. 
Many organizations including the governments set high ambitions, but quite a few ones are able to design and effectively execute wide-ranging change programs geared at delivering considerable performance improvements (Rajapakse, 2015). This has led to extensive discussion of the changes that are taking place in rural development. We are made to believe that everything would be for the best of interest of all if we followed the development model tested somewhere else. In this sense, "the myth of development constitutes part of the social imaginary of western societies" (Tucker, 1999, p. 2; also see Dhungana \& Pfefferle's article in this issue). This may be the reason that - despite the transfer of goods, services and funds - the socioeconomic undertakings of the West cannot be simulated in other societies (Tucker, 1999). It is because every society has its own shared beliefs and norms that form an essential part of the fabric of society. Once it becomes clear that the practices that we call development depend on shared beliefs rather than on predefined structure and model, it becomes possible to challenge them. Accepting this challenge will further enable us to examine to what extent we can customize the 'brought in models' (if any, for whatsoever reason) to fit our context, and envisage what our own shared practices can lead to local development. In 1976, a British statistician named George Box wrote the famous line, "All models are wrong, some are useful" (as cited in Clear, 2016, para. 5). We are to be careful about deciding on the useful models. Rajapakse (2015) cites the example of Saemaul Undong of Korea to be a success case of and model for rural village development including a movement for local self-governance (that fostered a corruption free transparent, equitable and a democratic culture), income increase, village modernization, mass mobilization, and agricultural revolution. Rajapakse (2015) further claims that no program of any other developing country has mobilized so much social, administrative and popular support, or brought about such a dramatic impact on community development and national integration as Saemaul Undong. The lesson we can draw from this case is that transformation initiatives devoid of public participation are bound to fail.

We have long been rethinking the whole concepts of development to cover a growing awareness of its gender, cultural and environmental dimensions (Munck \& O'Hearn, 1999). Moreover, the discourse of taking a more fundamental break with development as a Eurocentric concept is on the rise leading us to find local ways of knowing, being and educating (Parajuli, 2014). Till date, we have much celebrated the idea that transformation initiatives begin with a well laid strategies. And, we have almost championed in strategic planning. However, 


\section{R. K. Dhakal}

once the plans are set, the actual execution efforts often suffer a swift drop-off in focus (Butta, 2011). Such evidence makes us rethink over our follow-through modality and to find ways for accelerating our actions for execution. In our context, the government of Nepal has persistently given increased emphasis on rural development. We have observed Local Self-Governance Act (1999) which has devolved special power, authority, roles and responsibilities to the local bodies (Ministry of Local Development, 1999). Similarly, Social Welfare Act 1992 governs the provision of social welfare and social service activities; which allows the Social Welfare Council (SWC) to coordinate between the government and the social organizations, more specifically monitor or cause to monitor, evaluate and control the programmes and activities of the Civil Society Organizations (CSOs) including Non-Governmental Organizations (NGOs) and International Non-Governmental Organizations (INGOs) (Social Welfare Council, 1992). However, SWC's ability to reward the genuine I/NGOs and punish the wrongdoers is often questioned (Jha, 2015) even against the reported cases of malpractices of the existing CSOs. Therefore, it is important for the Government of Nepal to reform the legal framework that governs CSO activities in Nepal. Recently, the NGO Federation, in consultation with the Social Welfare Council, has also drafted the Social Development Act, however, it is yet (as of June 2016) to be approved (International Center for Not-for-Profit Law, 2016). It is heartening to note that the government has "rurbanized" (also see Gautam's article in this issue) intermediary villages/cities by turning rural villages and small towns into municipal units, so that they play effective roles in realizing the goals of rural development by offering a variety of social services, economic opportunities, and specialized services. The above evidence shows that there have been some efforts in promoting local bodies and regulating external investment, these are far from sufficient in addressing the rural transformation issues. What is lacking in these initiatives is the popular public participation. Therefore, maybe we should acknowledge the slogan "Nothing about us without us" (Lykketoft, 2015, para. 5 ) to be the prime agenda both in the planning process and in the implementation phase.

Rural transformation is not just inevitable, but possible. However, a formidable question at this juncture is 'But how?' The rural transformation agenda is about improving the quality of life in rural areas. This entails promoting investments in health, education, and rural infrastructure; having in place efficient rural financial markets; designing policies that promote greater gender 
equity and the empowerment of rural people, especially the most vulnerable through designing and implementing effective safety-net programs; improving market access of small-scale farmers in innovative markets and strengthen their involvement in the whole value chain (Boto, Fotabong, Proctor, Lopes, \& Kebe, 2012, p. 5). We have learned that rising to the transformation challenge requires new mindsets, skills, organizational designs, and more - all emerging from the concerned society, of course. Therefore, a response to these sorts of factors may be to adopt a "local" or even an "individual" approach (Hodge \& Midmore, 2008, p. 29), whereby all of our plans are shared and owned by everyone. This also enables our voice to find way in transforming our community, thereby we can connect the 'words' we speak with the 'world' we live. In doing so, we should adapt current sector-based rural strategies to take into account the different development needs and specific comparative advantages of rural communities and to have adequate resources directed towards particular problems at the individual household level. This is clearly an impossible task for a central or federal government and thus it demands a more localised approach (Hodge \& Midmore, 2008). Moreover, in order to come to terms with these processes, the political economy approach of development must be complemented by a critical examination of the local cultural practices (Munck \& O’Hearn, 1999) involved in sustaining the livelihood and in the production of local knowledge.

The discussion above led me to reflect on the following ideas. So much as the 'experts' from above and from outside keep telling us how to fix things and not let local solutions to emerge, rural transformation is next to impossible. Therefore, it is important to stop intervening rural societies so much as to befall them into a dependency trap. Instead, let the local leaders be accountable to their people and the development of their communities. Development partners rather than going local can promote greater policy awareness of the role of people's participation and people's organizations, especially women's groups, youth, indigenous people and people under occupation, local communities and small farmers, in sustainable rural development. Let local communities adopt a "local" approach to rural development. Evidently, "public resources for development assistance must be targeted on defined priorities" (Hodge \& Midmore, 2008, p. 31) based on local needs and local people must have control over such resources. It means there should be autonomy of the local people to self-govern and manage their development activities, even when foreign or government assistance is curbed. It is important to reiterate that rural transformation initiatives will be more 
sustainable if they rest on a local approach, complemented by state and external agencies (Boto et al., 2012). Support of the central or federal government to the local communities may therefore suffice in a level of investment in transportation, electricity, irrigation, education and health at a broad level. No other infrastructure are more evident in transforming rural societies. When we talk about agro-based rural transformation, it is crucial to promote people's participation on "farm technology development and transfer, incorporating indigenous ecological knowledge and practices" (United Nations Environment Programme, 1992, 14.22a). All other development priorities would emerge and follow locally.

I am now left in no doubt to reaffirm that we can make rural transformation happen since transformation begins with each one of us, and we are all an indispensable part of this transformative process. Further, we have realized that government action alone will not be enough, nor will the external support be. Therefore, our participation in all development activities whether they emerge from within or are delivered from outside will lead to a vibrant civil society action on the ground which creates pathways to rural transformation.

\section{References}

Arutyunova, A., \& Clark, C. (2013). Watering the leaves, starving the roots: The status of financing for women's rights organizing and gender equality. Ontario, Canada: Association for Women's Rights in Development. Atchoarena, D., \& Gasperini, L. (2003). Education for rural development: Towards new policy responses. Rome, Italy and Paris, France: FAO and UNESCO.

Boto, I., Fotabong, E., Proctor, F., Lopes, I., \& Kebe, H. (2012). Major drivers for rural transformation in Africa: Resources on rural transformation in Africa (Brussels Policy Brief No. 24). Retrieved from https://brusselsbriefings.files. wordpress.com/2009/02/ r18en1.pdf

Bozsahin, C. (2016). Natural recursion doesn't work that way: Automata in planning and syntax. In V. C. Muller (Ed.), Fundamental issues of artificial intelligence (pp. 95-112). Basel, Switzerland: Springer.

Butta, T. (2011, October 14). Making transformation happen. Retrieved from http://www.business2community.com/marketing/making-transformationhappen- 069209\#7ah1QLh8wWpCED 10.97

Clear, J. (2016). All models are wrong, some are useful. Retrieved from 
http://www.huffingtonpost.com/james-clear/all-models-are-wrongsome_b_11196880.html

Helin, C. (2006). Dances with dependency: Out of poverty through self-reliance. Vancouver, BC: Orca Spirit Publishing.

Helin, C. (2010). The economic dependency trap: Breaking free to self-reliance. New York, NY: Open Road Media.

Hemingway, E. (1926). The sun also rises. New York, NY: Scribner.

Hodge, I., \& Midmore, P. (2008). Models of rural development and approaches to analysis evaluation and decision-making. Economie Rurale, 307, 23-38. Retrieved from https://economierurale.revues.org/406

International Center for Not-for-Profit Law. (2016). NGO law monitor: Nepal. Retrieved from http://www.icnl.org/research/monitor/nepal.html

Jha, H. B. (2015, April 10). Rein them in: I/NGOs in Nepal. Retrieved from http:// admin.myrepublica.com/opinion/story/19029/rein.html

Lykketoft, M. (2015, November 25). The sustainable development goals:

Making transformation happen. Retrieved from http://www.huffingtonpost. com/mogens- lykketoft/the-sustainable-development-goals-makingtransformation- happen_b_8191230.html

Mauldin, J. (2014, June 14). Thoughts from the frontline: The age of transformation [Editorial]. Retrieved from http://www.mauldineconomics. com/editorial/thoughts-from- the-frontline-the-age-of-transformation

Ministry of Local Development. (1999). Local self-governance act 1999. Kathmandu, Nepal: Author.

Munck, R., \& O’Hearn, D. (1999). Preface. In R. Munck \& D. O’Hearn (Eds.), Critical development theory: Contributions to a new paradigm (pp. xiii-xx). New York, NY: Zed Books.

Parajuli, M. N. (2014). Realizing the existence of multiple forms of knowledge: A strategy towards seeing education for rural transformation. Journal of Education and Research, 4(2), 102-117.

Rajapakse, T. (2015, September 21). Managing complex change for sustainable rural transformation: Case of Saemaul Undong of Korea. Retrieved from https://www.linkedin.com/pulse/managing-complex-change-sustainable- 
$8 \mid$ R. K. Dhakal

rural-case- undong-rajapakse

Social Welfare Council. (1992). Social welfare act 1992. Kathmandu, Nepal: Author.

Tucker, V. (1999). The myth of development: A critique of a Eurocentric discourse. In R. Munck \& D. O'Hearn (Eds.), Critical development theory: Contributions to a new paradigm (pp. 1-26). London, England and New York, NY: Zed books.

United Nations Environment Programme. (1992). Rio declaration on environment and development. Nairobi, Kenya: Author.

Rebat Kumar Dhakal

School of Education, Kathmandu University

Email: rebat@kusoed.edu.np 